\title{
ANALISIS PERSEPSI KARYAWAN TERHADAP PRAKTEK- PRAKTEK ORGANISASIONAL TERKAIT LAYANAN DAN KOMITMEN ORGANISASIONAL SERTA PENGARUHNYA TERHADAP IKLIM LAYANAN PELANGGAN
}

\author{
Siti Nursyamsiah \\ Universitas Islam Indonesia \\ e-mail: S_Syamsiah@fe.uii.ac.id \\ Prapti Antarwiyati \\ Universitas Islam Indonesia \\ e-mail: antar@fe.uii.ac.id
}

\begin{abstract}
This study examines the relationships between certain organizational variables and employees 'perceptions of the customer service climate in their organization. The sample of study is the entire administration employee of Higher Education in Yogyakarta. The research has discovered some evidence that reward is not affecting employee's perception toward Customer service Climate. However, it is affecting the Organizational Commitment. If the employee's demand is accepted well by the management, then they will do the some thing to the customer. Hence, it will influence the organizational commitment. Providing sufficient Work Environment and Training able to show the institution efforts on employee's wealth. Other evidences show that, partially, Work Design, Work Environment and Training, mediated by Organization Commitment. This evidence shows the good working design, adequate working environment and training to employee will influence the increase of organizational commitment. Thus, it will influence the employee's perceptions towards Customer Service Climate.
\end{abstract}

Keywords: customer service climate, organizational commitment, employee perceptions

\section{PENDAHULUAN}

Memasuki abad 21 persaingan antar lembaga pendidikan tinggi semakin ketat. Apalagi pemerintah telah mengeluarkan kebijakan deregulasi pendidikan yang mengijinkan pihak asing untuk mendirikan perguruan tinggi baru di Indonesia. Dengan adanya deregulasi ini, maka persaingan antar perguruan tinggi, baik PTN maupun PTS akan semakin meningkat. Lembaga pendidikan tinggi yang ingin berkembang harus berkompetisi dan harus mampu menyediakan jasa yang berkualitas serta memusatkan perhatiannya pada kepuasan pelanggan, dan ini merupakan strategi pilihan bagi per- guruan tinggi yang ingin membedakan diri mereka dari kompetitornya.

Para pelanggan sekarang ini lebih menuntut dalam hal kualitas jasa yang mereka harapkan dari lembaga jasa. Penelitian yang dilakukan oleh Bennet (1992) menunjukkan bahwa pelanggan akan berpaling jika ada alternatif yang lebih baik yang tersedia pada lembaga jasa lain. Mereka lebih suka lembaga jasa yang membebankan harga yang lebih tinggi tetapi menyediakan layanan yang unggul dibandingkan dengan harga yang lebih rendah tetapi dengan pelayanan yang lebih buruk. 
Tuntutan-tuntutan pelanggan yang semakin meningkat akan kualitas jasa tersebut mengharuskan pihak manajemen/ pimpinan dan karyawan (dosen \& karyawan administrasi) memiliki komitmen terhadap pengembangan kualitas layanan yang diberikan oleh organisasi mereka.

Selain pengembangan kualitas layanan yang penting bagi karyawan, iklim layanan pelanggan juga vital jika organisasi ingin tetap kompetitif. Iklim Layanan Pelanggan merupakan sejumlah karakteristik deskriptive yang berhubungan dengan pemberian layanan dan kualitas layanan yang dapat digunakan oleh organisasi untuk membedakan diri dari organisasi lain dan mempengaruhi perilaku individu terkait dengan layanan dalam organisasi tersebut.

Para peneliti telah menunjukkan bahwa persepsi karyawan tentang iklim layanan terkait erat dengan persepsi pelanggan tentang layanan (Kelly, 1992, Reynerse dan harker, 1992, Scheider, 1980, Jourg Dietz,dkk,2004). Persepsi karyawan tentang iklim layanan dipengaruhi oleh persepsi karyawan tentang praktek-praktek organisasional yang terkait dengan layanan. Jika persepsi karyawan tentang praktek-praktek organisasional adalah positif, maka hal ini berpengaruh terhadap sikap karyawan yang tercermin pada perilaku karyawan dan ditransfer kepada pelanggan dalam bentuk layanan yang lebih baik (Scheider dan Bowen, 1993). Sebaliknya jika persepsi karyawan terhadap praktek-praktek organisasional yang terkait dengan layanan buruk, maka hal ini berakibat pada pengembangan sikap layanan pelanggan yang buruk dan menjalar ke pelanggan dalam bentuk kinerja layanan yang buruk.

Kelly (1992) telah mendiskripsikan usaha membangun sebuah iklim organisasional untuk layanan yang komponen-komponennya meliputi: dukungan manajemen dan sumberdaya yang memadai agar karyawan mampu melakukan layanan dengan baik.
Sebuah cara yang lebih nyata bagi manajemen untuk menunjukkan dukungan mereka pada layanan pelanggan adalah dengan mengimplementasikan program pemberian imbalan dan menghargai karyawan untuk keunggulan layanan yang telah mereka lakukan (David, dkk, 1996)

Manajemen juga bisa memberikan dukungan dengan cara memperhatikan suara karyawan tentang pekerjaan mereka. Jika karyawan merasa bahwa suara mereka bisa didengar dan mereka menerima sebuah komitmen manajemen untuk kualitas layanan, maka mereka bisa menjadi lebih sukses dalam mencapai layanan kualitas yang tinggi (Reaves dan Hoy, 1993).

Manajemen juga dapat mendorong penciptaan iklim layanan yang positif dengan menyediakan sumber daya yang memadai yang dibutuhkan karyawan untuk memberikan layanan yang efektif. Sumber daya tersebut meliputi perlengkapan yang sesuai, informasi yang memadai, penempatan staf yang sesuai, penyediaan peralatan serta lingkungan kerja yang baik (Scheider, dkk, 1993).

Adanya dukungan manajemen dan tersedianya sumber daya yang memadai terkait erat dengan respon emosional mendasar yang terkait dengan maksud layanan dan tercermin pada perilaku layanan pelanggan (Schit \& Allscheid, 1995). Oleh karena itu lembaga jasa dapat mempengaruhi karyawannya melalui praktekpraktek organisasional yang tepat, sehingga karyawan termotivasi untuk menyediakan layanan pelanggan yang lebih baik. Dengan demikian bermanfaat kiranya bagi organisasi untuk menemukan hal-hal yang memprediksi persepsi karyawan tentang praktekpraktek organisasional terkait dengan layanan dan pengaruhnya terhadap komitmen karyawan serta iklim layanan pelanggan. 


\section{KAJIAN PUSTAKA Iklim Layanan Pelanggan}

Iklim Layanan Pelanggan merupakan salah satu iklim organisasional yang mempengaruhi perilaku pekerja dalam suatu organisasi. Secara deskriptif Iklim organisasional merepresentasikan persepsi-persepsi anggota organisasi tentang kondisikondisi, faktor-faktor dan event-event yang terjadi dalam organisasi. Iklim organisasional juga dapat dipandang sebagai iklim yang dipresentasikan oleh persepsi-persepsi para pekerja tentang karakteristik-karakteristik obyektif dari sebuah organisasi (Landy, 1989. Angela Martin, 2008))

Menyediakan layanan yang berkualitas kepada pelanggan harus dimulai dari puncak hirarki organisasi. Organisasi bisa menanamkan nilai-nilai organisasi yang berhubungan dengan kualitas layanan pada pekerja baru selama proses sosialisai organisasional, sehingga akan terbentuk sebuah iklim organisasional untuk layanan tersebut. Kelley, (1992), mendefinisikan Iklim Layanan Pelanggan sebagai sejumlah karakteristik deskriftif yang berhubungan dengan pemberian layanan dan kualitas layanan yang bisa digunakan oleh sebuah organisasi untuk membedakan diri dari organisasi lain dan mempengaruhi perilaku individu yang terkait dengan layanan di dalam organisasi tersebut.

Beberapa ahli memperdebatkan apakah komponen-komponen dari iklim merupakan atribut-atribut aktual organisasi atau sekedar persepsi-persepsi para pekerja yang bekerja dalam organisasi tersebut. Untuk menjawab pertanyaan ini ada 3 pendekatan yang bisa digunakan untuk mengukur iklim organisasioanal. Pendekatan pertama, The Multiple measurement organizational approach, dimana pendekatan ini mengukur iklim dengan beragam metode dan atribut-atribut atau efek-efek utamanya akan mencakup variabel-variabel ukuran, struktur, kompleksitas sistem, gaya kepemimpinan dan arah sasaran. Kedua, The perceptual measurement -organizational attribute approach. Pendekatan ini memandang iklim sebagai sebuah atribut organisasional, dimana karakteristik-karakteristik organisasi diukur dari sisi persepsi-persepsi pekerja tentang dimensi-dimensi iklim. The perceptual measurement - individual attribute approach, dimana pendekatan ini memandang iklim sebagai seperangkat persepsi persepsi ringkasan atau global yang merefleksikan suatu interaksi antara eveneven aktual dalam organisasi dan persepsi pekerja tentang even-even tersebut.

Beragam ukuran iklim organisasional telah dikembangkan untuk mengukur iklim di kebanyakan type organisasi. Kuesioner Iklim Organisasional Litwin dan Stringer (LSOCQ) paling sering digunakan dalam organisasi-organisasi. Dimensi-dimensi yang digunakan untuk mengukur Iklim menurut LSOCQ adalah:

a. Struktur: mengindikasikan perasaan yang dipunyai pekerja tentang kendalakendala dalam kelompok, berapa banyak aturan aturan, prosedurprosedur yang ada.

b. Tanggung jawab: merupakan perasaan menjadi boss pada diri anda sendiri, tidak harus mengecek dua kali semua keputusan anda, tahu akan tugas yang menjadi pekerjaan anda.

c. Reward: merupakan perasaan dihargai untuk sesuatu yang sudah dikerjakan dengan baik, kebijakan yang fair tentang imbalan dan promosi.

d. Risiko: adalah perasaan adanya tantangan dalam pekerjaan dan organisasi.

e. Kehangatan; adalah perasaan pertemanan yang baik dalam atmosfir kelompok kerja.

f. Dukungan: yaitu sikap suka membantu dari manajer dan para pekerja lain dalam kelompok.

g. Standar: yakni standar - standar kinerja yang jelas. 
h. Konflik: adalah perasaan bahwa atasan dan para pekerja ingin mendengarkan opini-opini yang berbeda.

i. Identitas: adalah perasaan bahwa anda menjadi bagian dari sebuah tim kerja.

\section{Komitmen Organisasional}

Komitmen organisasional didefinisikan sebagai sebuah kelekatan psikhologis yang dirasakan oleh seseorang pada organisasi. (David, dkk, 1996). Komitmen terhadap organisasi bisa menguntungkan manajemen dalam beberapa hal. Pertama, memiliki karyawan dengan komitmen tinggi akan mengurangi pergantian karyawan, yang oleh karenanya mengurangi biaya perputaran tenaga kerja. Komitmen juga berpengaruh terhadap kinerja (Van Maanen, 1976). Lebih jauh komitmen organisaional juga mampu memprediksi loyalitas pelanggan. (Ulrich, dkk, 1991). Jika karyawan memiliki komitmen pada sebuah organisasi dan pelanggan menerima komitmen tersebut, maka pelanggan juga cenderung memiliki komitmen terhadap organisasi tersebut.

Di dalam penelitian yang dilakukan O`reilly dan Chatman (1986), komitmen organisaional dibagi menjadi tiga dimensi: yakni pemenuhan (keterlibatan instrumental untuk imbalan khusus dan intrinsik), Identifikasi (keterlibatan yang didasarkan pada hasrat untuk berafiliasi) dan Internalisasi (keterlibatan yang didasarkan pada kesesuaian diantara nilai-nilai individual dan organisasional).

Keterlibatan karyawan dapat diartikan suatu proses untuk mengikutsertakan para karyawan pada semua level organisasi dalam pembuatan keputusan dan pemecahan masalah. Tujuan pelibatan karyawan adalah untuk meningkatkan kemampuan organisasi untuk memberikan customer value. Oleh karena itu karyawan harus memahami apa itu customer value, komponen sistem, dan bagaimana untuk menentukan dan mengukur customer value.

Faktor komitmen sangat penting, karena karyawan yang memiliki komitmen terhadap organisasi akan memiliki sikap yang profesional dan menjunjung tinggi nilai-nilai yang telah disepakati dalam organisasi. Komitmen yang tinggi menjadikan iklim layanan yang positip dan akan mempengaruhi kepuasan dan loyalitas pekerja pada organisasi mereka (Voon, 2009).

Membangun komitmen karyawan sangat terkait dengan bagaimana komitmen organisasi terhadap karyawannya. Bagaimana organisasi memberi layanan pada karyawannya sangat menentukan puas/tidaknya karyawan yang bersangkutan, dan pada akhirnya menumbuhkan komitmen karyawan pada organisasi.

Hubungan Persepsi Pekerja tentang
Praktek-Praktek Organisasional, Komit-
men Organisasional dan Iklim Layanan
Pelanggan
Persepsi pekerja tentang iklim layanan terkait erat dengan persepsi pelanggan tentang layanan (Kelley, 1992, Schneider, 1980, Shneider \& Bowen, 1985) dan penilaian kepuasan pelanggan (Reinierse \& Harker, 1992, Tornow \& Wiley, 1991). Sebagian besar penelitian ini dilakukan pada industri perbankan, dimana para pelanggan dan pekerja unit layanan sering berinteraksi satu sama lain, dan layanan pelanggan seringkali merupakan satusatunya yang membedakan sebuah bank dari kompetitornya.

Schneider, dkk, (1980), mewawancarai para pekerja dan pelanggan dari 23 cabang bank dan meminta mereka untuk mendiskripsikan praktek-praktek dan prosedur-prosedur cabang mereka yang berhubungan dengan ketentuan layanan pelanggan. Didasarkan pada jawaban lebih dari 250 pekerja dan 1600 pelanggan, 
ternyata ditemukan hubungan yang positif diantara beberapa dimensi "iklim untuk layanan" pekerja, seperti pendukung system (contoh: staf yang memadai) dan dukungan logistik, serta beberapa dimensi "iklim untuk layanan" pelanggan, seperti kesopanan, semangat pekerja dan administrasi cabang. Disamping itu ditemukan sebuah korelasi yang positip antara persepsi pekerja tentang level kualitas layanan yang ditawarkan dengan persepsi pelanggan tentang layanan pelanggan.

Di dalam sebuah penelitian lanjutan yang dilakukan Schneider \& Bowen (1985), menemukan hubungan yang positip antara sikap pekerja dan sikap pelanggan tentang kualitas layanan pelanggan. Persepsi pekerja tentang praktek-praktek sumber daya manusia umum juga terkait dengan persepsi iklim layanan pelanggan. Jika pekerja merasa bahwa organisasi mereka menyediakan supervisi yang sesuai, mempertinggi status dan peluang karir mereka, dan menyediakan fasilitas untuk pekerjaan mereka, maka persepsi mereka tentang iklim layanan pelanggan di dalam organisasi mereka akan berkembang dan pelanggan merasakan layanan tersebut sebagai lebih baik.

Namun demikian bank bukan satusatunya industri dimana penelitian tentang persepsi pekerja dan pelanggan tentang layanan telah dilakukan. Tornow \& Wiley (1991), mengukur sikap pekerja dan level kepuasan pelanggan melalui survey pada sebuah divisi utama dari perusahaan komputer multinasional. Didasarkan pada jawaban responden, maka ditemukan hubungan yang positip antara persepsi pekerja tentang praktek-praktek organisasional yang berhubungan dengan layanan terhadap kepuasan pelanggan.

Hubungan yang konsisten positip telah ditemukan diantara persepsi pekerja dan pelanggan tentang iklim layanan di sejumlah lingkungan kerja yang berbeda. Oleh karena itu, organisasi jasa harus mengembangkan praktek-praktek organisasional terkait layanan. Sebuah cara yang lebih nyata bagi manajemen untuk menunjukkan dukungan mereka pada layanan pelanggan adalah dengan mengimplementasikan program pemberian imbalan dan menghargai pekerja untuk keunggulan layanan yang telah mereka lakukan. Sistem reward yang tepat memiliki suatu dampak kuat pada sikap dan perilaku pekerja dan menjadi motivasi pekerja di dalam menjalankan pekerjaannya.

Membuat pelanggan senang memerlukan penelitian yang terus menerus dan umpan balik dari pelanggan tentang kebutuhan dan keinginan mereka. Manajemen bisa menunjukkan dukungan mereka dengan menyediakan layanan pelanggan yang berkualitas dengan cara mendengar suara pekerja yang memiliki hubungan langsung dengan pelanggan. Pihak manajemen harus mau mendengar suara pekerja tentang pekerjaan mereka dan persepsi mereka tentang pelanggan (Messmer, 1994). Hal ini disebabkan karena para pekerja yang berhubungan langsung dengan pelanggan lebih tahu apakah pelanggan merasa puas atau tidak Jika pekerja berfikir bahwa suara mereka bisa didengar dan mereka menerima sebuah komitmen manajemen untuk kualitas layanan, mereka dapat menjadi lebih sukses dalam mencapai layanan kualitas tinggi (Reeves \& Hoy, 1993).

Organisasi dapat membantu mendorong penciptaan iklim layanan yang unggul dengan menyediakan pekerja dengan sumber daya yang memadai yang mereka butuhkan untuk memberikan layanan yang efektif (Schneider, dkk, 1993), meliputi level penempatan staf yang sesuai, perlengkapan yang sesuai, dan informasi yang memadai yang memungkinkan pekerja melakukan pekerjaan mereka dengan baik.

Manajemen dapat membantu memperendah hambatan organisasional yang bisa menghambat kinerja layanan pelanggan. 
Menurut Brown \& Mitchell (1993), hambatan organisasional adalah faktor yang berada di dalam lingkungan kerja yang memiliki kemampuan untuk membatasi performance. Mereka mengkategorikan hambatan menjadi dua kategori, yakni hambatan teknis dan hambatan sosial. Hambatan teknis adalah hambatan yang melibatkan peralatan, perlengkapan, system atau aturan. Contohnya adalah pekerjaan yang didesain kurang bagus, informasi dan perlengkapan yang kurang memadai dan lingkungan kerja fisik yang buruk. Sedangkan hambatan sosial adalah hambatan yang melibatkan interaksi antar individu-individu dalam organisasi tersebut. Misalnya penempatan staff yang tidak sesuai, pelatihan yang tidak memadai, atau kurangnya otoritas pembuat keputusan formal.

Pada umumnya semakin banyak hambatan yang diterima oleh pekerja, maka semakin rendah level kepuasan pelanggan. Sebaliknya, ketika pekerja percaya bahwa pekerjaan mereka didukung dengan fasilitas yang memadai, para pelanggan menerima layanan yang lebih baik (Schneider \& Bowen, 1985).

Untuk mengurangi hambatan teknis, manajemen harus menyediakan sumber daya yang memadai bagi pekerja untuk melakukan pekerjaan mereka dengan baik. Organisasi yang menekankan layanan pelanggan bisa melakukannya dengan menyediakan perlengkapan yang sesuai, seperti system komputer terbaru dan mudah digunakan, dan memastikan bahwa pekerja memilki informasi yang mereka perlukan untuk melakukan pekerjaan mereka secara memadai.

Hambatan teknis juga dapat dikurangi dengan cara mendesain pekerjaan secara memadai untuk menangani aliran kerja yang normal. Melakukan training yang sesuai dengan kebutuhan pekerja juga ditenggarai dapat meningkatkan kepuasan kerja (Amanda Beatson, 2008). Menyedia- kan sebuah lingkungan kerja yang kondusif juga sangat penting dan bisa membantu menyampaikan komitmen manajemen untuk menyediakan sebuah iklim layanan pelanggan yang positif. Ketika lingkungan kerja dipahami pekerja sebagi sebuah hambatan, maka para pelanggan akan merasa tidak puas (Brown \& Mitchell, 1993). Sebaliknya, jika pekerja mendeskripsikan lingkungan kerja mereka secara positif, maka penilaian kepuasan pelanggan yang tinggi akan dihasilkan (Wiley, 1991).

Manajemen juga dapat menyediakan sumber daya untuk mengurangi hambatan sosial, seperti penempatan staff yang sesuai untuk merespon pelanggan selama periode sibuk, menyediakan pekerja dengan otoritas pembuat keputusan yang sesuai dan pelatihan yang memadai untuk melakukan pekerjaan mereka dengan baik. Faktorfaktor tersebut akan mempengaruhi persepsi pekerja tentang iklim layanan pelanggan dan mengurangi hambatan untuk kinerja layanan yang efektif.

Usaha manajemen untuk menciptakan sebuah iklim organisasional untuk layanan tidak hanya mempengaruhi persepsi pekerja tentang iklim layanan, tetapi juga bisa mengarah pada komitmen pekerja terhadap organisasi. Jika pekerja memahami bahwa manajemen memiliki komitmen terhadap gagasan layanan berkualitas dan memberi mereka imbalan, pelatihan, penempatan staff yang sesuai, dukungan fasilitas dan lingkungan kerja yang kondusif serta informasi yang tepat, maka komitmen pekerja terhadap organisasi semakin meningkat Pekerja yang memiliki komitmen yang tinggi terhadap organisasi cenderung memiliki persepsi yang baik tentang iklim layanan pelanggan.

Ketika sebuah organisasi menyediakan dukungan dan sumber daya yang memadai bagi pekerja, maka akan menyebabkan pekerja mengulang-ulang level tinggi komitmen organisasional mereka. 
Ada kecenderungan bahwa pekerja dengan level komitmen yang tinggi akan melakukan lebih banyak usaha atas nama organisasi dan lebih jauh lagi akan menyediakan level layanan pelanggan yang tinggi. Selanjutnya akan mengarah pada persepsi tentang iklim layanan yang lebih positif.

\section{PERUMUSAN HIPOTESIS}

Berdasarkan hasil penelitian dari peneliti-peneliti sebelumnya diperoleh kesimpulan bahwa faktor - faktor yang mempengaruhi persepsi pekerja terhadap iklim layanan pelanggan dapat dikategorikan menjadi tiga kelompok:

1. Faktor yang memberi rasa penghargaan terhadap pekerja, seperti pemberian imbalan (Reward) yang layak pada pekerja atas layanan pelanggan yang telah dilakukannya dan kemauan manajemen untuk mendengar suara pekerja (Employee Voice) yang memiliki hubungan langsung dengan pelanggan.

2. Dukungan manajemen untuk memperkecil hambatan teknis yang berhubungan dengan layanan pelanggan, dengan menyediakan "peralatan teknologi yang sesuai dan informasi kerja yang tepat", "pekerjaan yang didesain dengan baik", dan" penciptaan lingkungan kerja yang kondusif".

3. Dukungan manajemen untuk memperkecil hambatan sosial pekerja ditempat kerjanya, seperti memberi "pelatihan yang memadai".

Faktor-faktor tersebut dapat mempengaruhi secara langsung terhadap persepsi pekerja tentang iklim layanan pelanggan. Beberapa penelitian juga menemukan hubunganhubungan yang tidak langsung dimana komitmen organisasional ditenggarai sebagai penghubung diantara kondisi organisasional dengan iklim layanan, seperti yang diilustrasikan pada model penelitian pada gambar 1.

Atas dasar pengelompokkan faktorfaktor tersebut maka hipotesis penelitian ini disusun sebagai berikut:

H1 : Persepsi pekerja tentang komitmen manajemen terhadap layanan pelanggan, yang tercermin pada "imbalan dan pengakuan pihak manajemen terhadap pekerja atas keunggulan layanan" akan mempengaruhi persepsi pekerja yang mendukung iklim layanan pelanggan

$\mathrm{H} 2$ : Persepsi pekerja tentang komitmen manajemen terhadap layanan pelanggan, yang tercermin "kemauan manajemen untuk mendengar suara pekerja yang memiliki hubungan langsung dengan pelanggan", akan mempengaruhi persepsi pekerja yang mendukung iklim layanan pelanggan.

H3 : Persepsi pekerja tentang komitmen manajemen yang mampu menyediakan sumber daya yang memadai untuk memperendah hambatan teknis dengan menyediakan "peralatan teknologi yang sesuai dan informasi kerja yang tepat", maka akan berpengaruh terhadap "persepsi pekerja tentang iklim layanan pelanggan". 


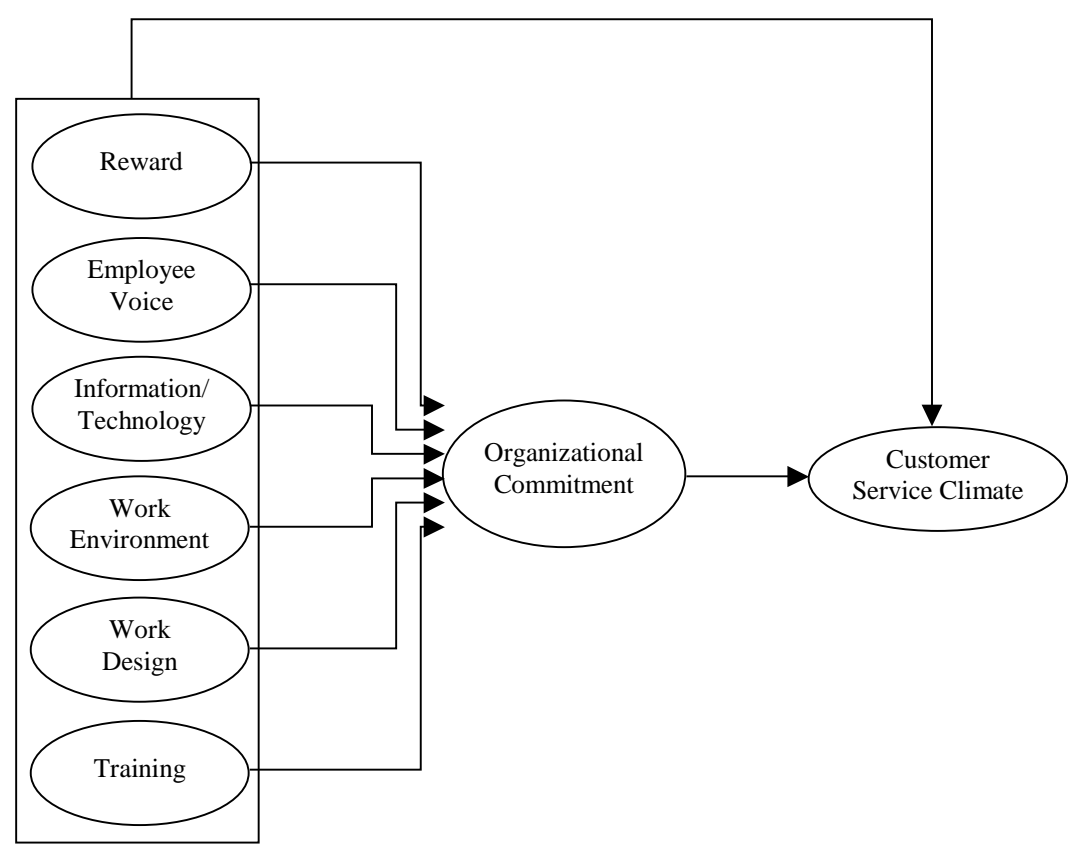

Gambar 1: Hubungan antara Praktek-Praktek Organisasional, Komitmen organisasi dan Persepsi Pekerja tentang Iklim Layanan Pelanggan.

H4 : Persepsi pekerja tentang komitmen manajemen yang mampu menyediakan sumber daya yang memadai untuk memperendah hambatan teknis dengan menyediakan "pekerjaan yang didesain dengan baik", maka akan berpengaruh terhadap "persepsi pekerja tentang iklim layanan pelanggan".

H5 : Persepsi pekerja tentang komitmen manajemen yang mampu menyediakan sumber daya yang memadai untuk memperendah hambatan teknis dengan menyediakan " penciptaan lingkungan kerja yang kondusif', maka akan berpengaruh terhadap "persepsi pekerja tentang iklim layanan pelanggan".

H6 : Persepsi pekerja tentang komitmen manajemn yang mampu menyediakan sumber daya untuk memperendah hambatan sosial atas kinerja layanan pelanggan, seperti "pelatihan yang memadai", maka akan mempengaruhi "persepsi pekerja tentang iklim layanan pelanggan"

H7 : Persepsi pekerja tentang komitmen manajemen yang memberikan" imbalan", "mendengarkan suara pekerja", "memberi pelatihan", "menyediakan teknologi dan informasi", menyediakan "lingkungan kerja yang memadai" dan "desain pekerjaan yang baik" terkait dengan layanan pelanggan akan berpengaruh pada "komitmen pekerja terhadap organisasi”.

H8 : Komitmen pekerja terhadap organisasi akan berpengaruh secara positif terhadap persepsi pekerja tentang iklim layanan pelanggan.

H9 : Komitmen organisasi secara parsial menjadi mediasi yang menghubungkan antara komitmen manajemen ter- 
kait dengan layanan pelangggan yang tercermin dari pemberian imbalan, mendengarkan suara pekerja, memberi pelatihan, menyediakan teknologi dan informasi, menyediakan lingkungan kerja yang memadai dan desain pekerjaan yang baik dengan persepsi pekerja tentang iklim layanan pelanggan.

\section{METODE PENELITIAN \\ Pengumpulan Data dan penentuan Sampel}

Data penelitian dikumpulkan melalui penyebaran kuesioner yang ditujukan pada karyawan non edukatif unit layanan pada Perguruan Tinggi di Yogyakarta. Sampel diambil secara acak pada karyawan tersebut.

Dalam penelitian ini pengambilan sampel dilakukan dengan menentukan tingkat presisi melalui error maksimum sebesar 0,25 dengan tingkat keyakinan 90\%. Sampel yang diambil sebanyak 62 responden: Dari 62 kuesioner yang dibagikan, hanya 60 kuesioner yang dikembalikan, namun 7 diantaranya tidak memberikan data yang lengkap sehingga tidak bisa digunakan dalam analisis data. Sampel akhir dalam penelitian ini sebanyak 53, terdiri dari karyawan bagian akademik 15 orang, bagian perpustakaan 12 orang, bagian SIM 4 orang, Bagian Keuangan 5 orang, bagian Umum dan Jurnal 9 orang dan bagian rumah tangga 8 orang.

\section{Definisi dan Pengukuran Variabel}

Untuk mengukur variable-variabel dalam penelitian ini menggunakan instrumen yang dikembangkan oleh David J Lux, dkk, (1996).

\section{Variabel bebas}

Variabel bebas dalam penelitian ini adalah prediktor-prediktor persepsi pelayanan, terdiri atas Imbalan (RW), Suara Pekerja (EV), Pelatihan (TR), Informasi dan
Teknologi (IT), Lingkungan Kerja (WE), serta Desain Kerja (WD).

Untuk menguji hipotesis riset, masing-masing variable diukur dengan menggunakan instrumen dalam bentuk kuesioner. Penciptaan skala dilakukan dengan menggunakan pendekatan statistik dengan menggunakan Pearson Product Moment Test.

Skala suara pekerja (EV) yang berisi item-item yang mengukur persepsi pekerja tentang input pekerja ke dalam pembuatan keputusan-keputusan organisasional. Skala Pelatihan (TR) berisi item-item yang mengukur persepsi pekerja bahwa mereka menerima pelatihan yang memadai. Skala Informasi dan Teknologi (IT) berisi itemitem yang mengukur persepsi pekerja bahwa mereka memiliki perlengkapan dan teknologi yang diperlukan untuk melakukan pekerjaan mereka. Skala Lingkungan Kerja (WE) terdiri dari item-item yang berhubungan dengan kondisi kerja fisik. Skala Desain Kerja (WD) mengukur kepuasan kerja pekerja dengan aspek-aspek desain pekerjaan mereka.

Masing-masing item menggunakan skala likert satu sampai empat, dimana angka satu mewakili jawaban "sangat tidak setuju" dan angka empat mewakili jawaban "sangat setuju". Untuk variabel Lingkungan kerja (WE), angka satu mewakili jawaban "sangat tidak puas" dan angka empat mewakili jawaban "sangat puas".

\section{Variabel terikat}

Variabel terikat dalam penelitian ini adalah iklim layanan pelanggan (CSC). Skala iklim layanan pelangan berisi itemitem yang mengukur iklim yang terbentuk pada organisasi tersebut terkait layanan pelanggan serta persepsi pekerja pada kualitas layanan yang diberikan pada pelanggan. Masing-masing item pertanyaan diukur dengan menggunakan skala likert satu sampai empat, dimana angka satu 
mewakili jawaban "sangat tidak setuju" dan angka empat mewakili jawaban "sangat setuju".

\section{Variabel intervening}

Variabel Intervening merupakan variabel antara atau mediating variable yang menghubungkan antara variabel independen dengan variabel dependen. Variabel Intervening dalam penelitian ini adalah komitmen organisasi (OC).

Skala komitmen organisasi berisi item-item yang mengukur persepsi pekerja terhadap komitmennya pada organisasi Masing-masing item diukur dengan menggunakan skala likert satu sampai empat, dimana angka satu mewakili jawaban "sangat tidak setuju" dan angka empat mewakili jawaban "sangat setuju".

\section{HASIL DAN PEMBAHASAN}

Analisa Prediktor Iklim Layanan Berdasarkan Unit Kerja

Hasil jawaban responden berdasarkan Unit kerja menunjukkan tingkat kepuasan karyawan terhadap penghargaan dari institusi (RW) paling tinggi di diakui oleh bagian akademik $(3,20)$ sedangkan paling rendah di akui di bagian SIM $(2,69)$. Untuk bagian yang lain menyatakan bahwa imbalan yang diterima masih pada tingkat kurang memuaskan.

Peran karyawan dalam pembuatan keputusan organisasional (EV) yang mencapai nilai lebih dari 3 di bagian Rumah tangga $(3,15)$ dan Bagian Akademik $(3,02)$ ini berarti bahwa bagian Rumah tangga dan bagian Akademik merasa bahwa pekerjaan yang dilakukan mempunyai peran dalam pembuatan keputusan organisasi. Para karyawan yang ada dibagian Rumah Tangga dan Akademik telah dilibatkan dalam pengambilan keputusan organisasi. Sedangkan dibagian lain karyawan merasa kurang dilibatkan dalam pembuatan keputusan organisasi.terutama pada bagian Perpustakaan yang mencapai nilai (2.61).

Pelatihan /training yang memadai yang didapatkan karyawan (TR) mempunyai nilai kurang dari 3 berarti seluruh unit kerja merasa bahwa pelatihan-pelatihan yang diperoleh masih belum memadai dan belum sesuai pengembangan kemampuan yang dibutuhkan.

Persepsi karyawan terhadap Teknologi Informasi yang dimiliki institusi untuk keperluan pekerjaan yang dilakukan (TI) rata-rata memiliki nilai lebih dari 3 yaitu di Bagian Akademik (3,12), Bagian SIM $(3,39)$ dan di Bagian Rumah Tangga $(3,27)$. Ini berarti di ke 3 bagian tersebut telah memiliki cukup hardaware dan software yang diperlukan serta memiliki informasi dan mampu memanfaatkan computer secara efektif. Untuk bagian lain mencapai nilai rata-rata 2,9 yang berarti telah mendekati cukup untuk menggunakan computer secara efektif.

Persepsi karyawan tentang lingkungan kerja yang disediakan institusi (Work Enviromental= WE) Yang mencapai nilai 3 adalah bagian Keuangan dan bagian Rumah Tangga. Berarti ke dua bagian ini telah merasa puas dengan kondisi dan lingkungan kerja yang ada dibagiannya. Sedangkan dibagian lain menyatakan kurang merasa puas dengan kondisi dan lingkungan kerjanya yang dinyatakan dengan nilai ratarata 2,7 .

Persepsi karyawan tentang kepuasan aspek design (Work Design = WD) atas pekerjaannya yang mencapai nilai kurang memuaskan terjadi di bagian Perpustakaan sebesar 2,63 dan dibagian Umum \& Jurnal sebesar 2,83 sedangkan di bagian lain menyatakan bahwa aspek design pekerjaan telah memuaskan. 
Tabel 1: Jawaban Responden Berdasar Unit Kerja

\begin{tabular}{|c|c|c|c|c|c|c|c|c|c|}
\hline \multirow{2}{*}{ Unit Kerja } & \multirow{2}{*}{$\mathrm{N}$} & \multicolumn{8}{|c|}{ Nilai Rata-rata } \\
\hline & & RW & $\mathrm{EV}$ & $\mathrm{TR}$ & TI & WE & WD & $\mathrm{CSC}$ & OC \\
\hline Bagian Akademik & 15 & 3,20 & 3,02 & 2,88 & 3,12 & 2,90 & 3,03 & 3,15 & 3,15 \\
\hline Bagian Perpustakaan & 12 & 3,02 & 2,61 & 2,71 & 2,93 & 2,70 & 2,64 & 2,69 & 2,98 \\
\hline Bagian SIM & 4 & 2,69 & 2,92 & 2,63 & 3,39 & 2,79 & 3,00 & 2,82 & 3,21 \\
\hline Bagian Keuangan & 5 & 2,95 & 2,77 & 2,70 & 2,91 & 3,00 & 3,37 & 3,14 & 3,06 \\
\hline Bagian Umum \& Jurnal & 9 & 2,94 & 2,80 & 2,53 & 2,92 & 2,79 & 2,83 & 3,03 & 3,03 \\
\hline Bagian Rumah Tangga & 8 & 2,78 & 3,15 & 2,98 & 3,27 & 3.02 & 3,13 & 3,21 & 3,00 \\
\hline
\end{tabular}

Persepsi karyawan terhadap iklim layanan pelanggan (Customer Service Committee $=$ CMC) yang mencapai nilai kurang memuaskan terjadi di bagian Perpustakaan sebesar 2,69 dan di bagian SIM sebesar 2,82 sedangkan dibagian lain mencapai nilai lebih dari 3 yang menyatakan bahwa karyawan memahami berbagai aspek berkaitan dengan pelayanan pelanggan.

Komitmen karyawan terhadap organisasi (Organizational Comitment = OC) seluruh unit kerja menyatakan adanya komitmen dengan organisasi yang dinyatakan dalam nilai 3 keatas hanya dibagian Perpustakaan nilai yang dicapai sebesar 2,98 yang hal ini mendekati 3 .

Analisa Prediktor Iklim Layanan Berdasarkan Tingkat Pendidikan

Hasil jawaban responden berdasarkan Unit kerja yang ada seperti pada tabel 2 . berikut ini Dari tabel tersebut dapat diketahui bahwa untuk tingkat kepuasan karyawan terhadap penghargaan dari institusi (Reward $=$ RW) diakui oleh karyawan yang memiliki pendidikan SMP dan SMU sedangkan untuk tingkatan pendidikan S1 dan D3 dirasa imbalan yang diterima kurang memuaskan.

Peran karyawan dalam pembuatan keputusan organisasional (Employment Voice $=\mathrm{EV}$ ) diakui oleh karyawan dengan tingkat pendidikan S1 dinyatakan berperan walaupun pada tingkatan nilai kurang dari 3 dan pada tingkatan D3 memberikan nilai peran terendah.

Pelatihan /training yang memadai yang didapatkan karyawan (TR) mempunyai nilai kurang dari 3 berarti pada semua tingkat pendidikan merasa bahwa training dan pengembangan karyawan yang diterima masih belum memuaskan.

Tabel 2: Jawaban responden berdasar Tingkat Pendidikan

\begin{tabular}{lcrrrrrrrr}
\hline \multirow{2}{*}{ Tingkat pendidikan } & \multirow{2}{c}{ N } & \multicolumn{10}{c}{ Nilai Rata-rata } \\
\cline { 3 - 10 } & & RW & EV & TR & TI & WE & WD & CSC & OC \\
\hline SMP & 1 & 3,25 & 3,83 & 2,88 & 3,57 & 1,86 & 2,50 & 3,43 & 3,43 \\
SMU & 42 & 3,02 & 2,86 & 2,76 & 3.04 & 2.86 & 2,89 & 2,96 & 3.02 \\
D3 & 4 & 2,69 & 2,75 & 2,75 & 3,18 & 2,82 & 3,17 & 3,11 & 3,07 \\
S1 & 6 & 2,96 & 2,94 & 2,73 & 3,12 & 2,98 & 3,31 & 3,21 & 3,33 \\
\hline
\end{tabular}


Persepsi karyawan terhadap Teknologi Informasi yang dimiliki institusi untuk keperluan pekerjaan (TI), pada semua jenjang pendidikan memberikan nilai lebih dari 3. Hal ini berarti bahwa semua jenjang pendidikan telah merasa merasa bahwa TI yang disediakan oleh Fakultas benar-benar sudah sesuai dengan kebutuhan pekerjaannya.

Berkenaan dengan persepsi karyawan tentang lingkungan kerja yang disediakan institusi (WE), untuk jenjang pendidikan S1 merasa mendekati memuaskan. Untuk jenjang D3 dan SMU mencapai nilai kurang dari 3 berarti kutang memuaskan sedangkan pada karyawan yang mempunyai pendidikan SMP menyatakan bahwa lingkungan kerja sangat tidak memuaskan.

Pada aspek kepuasan Design pekerjaan (WD), untuk karyawan dengan jenjang pendidikan S1 dan D3 memberikan nilai lebih dari 3 yang berarti merasa puas atas Design Pekerjaan yang ada di lingkungannya, untuk karyawan dengan jenjang SMU dan SMP memberikan nilai kurang dari 3 yang berarti menyatakan ketidak puasan atas design pekerjaan yang ada dilingkungannya.

Persepsi terhadap iklim layanan pelanggan (CSC) dinyatakan memuaskan untuk semua jenjang pendidikan. Hal ini dinyatakan dengan nilai lebih dari 3 dan hanya pada tingkat pendidikan SMU memberikan nilai 2,96 .
Komitmen karyawan terhadap Organisasi (OC) dirasa memuaskan untuk semua tingkatan pendidikan dengan nilai lebih dari 3.

\section{Analisa Prediktor Iklim Layanan Berdasarkan Masa Kerja}

Jawaban responden terhadap variabel-variabel penelitian yang ditanyakan lewat kuesioner berdasarkan masa kerja karyawan secara lengkap tersaji pada table 3. Dari tabel tersebut dapat diketahui bahwa untuk tingkat kepuasan karyawan terhadap penghargaan dari institusi (Reward $=\mathrm{RW}$ ) yang mempunyai nilai tertinggi $(3,58)$ ada pada golongan karyawan yang memiliki masa kerja $>25,5$ tahun sedangkan pada karyawan dengan masa golongan 15,5 s/d 20 tahun memberikan nilai terendah $(2,72)$ yang merasa bahwa imbalan yang diterima belum memuaskan. Untuk golongan masa kerja yang lain memberikan nilai 3 keatas yang berarti reward yang diterima telah memuaskan.

Peran karyawan dalam pembuatan keputusan organisasional (EV). Pada karyawan golongan masa kerja 2,5 th s/d 5 th dan masa kerja 15,5 s/d 20 th yang merasa memiliki peran dalam pembuatan keputusan organisasi yang dinyatakan dengan nilai lebih dari 3. Sedangkan pada golongan masa kerja yang lain merasa tidak berperan, yang terendah menyatakan tidak berperan pada golongan masa kerja $>25,5$ th dengan nilai 2,6 .

Tabel 3: Jawaban Responden Berdasar Masa Kerja

\begin{tabular}{llrrrrrrrr}
\hline \multirow{2}{*}{ Masa Kerja } & \multirow{2}{*}{$\mathrm{N}$} & \multicolumn{10}{c}{ Nilai Rata-rata } \\
\cline { 3 - 9 } & & RW & EV & TR & TI & WE & WD & CSC & OC \\
\hline $2-5$ tahun & 5 & 2,98 & 3,10 & 3,05 & 3,37 & 3,46 & 3,47 & 3,34 & 3,34 \\
$5,5-10$ tahun & 16 & 3,02 & 2,73 & 2,73 & 2,97 & 2,66 & 2,67 & 2,29 & 3,00 \\
$10,5-15$ tahun & 11 & 3,07 & 2,73 & 2,80 & 3,09 & 2,69 & 2,87 & 2,89 & 3,06 \\
$15,5-20$ tahun & 8 & 2,72 & 3,04 & 2,75 & 3,11 & 2,64 & 2,73 & 3,20 & 2,98 \\
$20,5-25$ tahun & 10 & 3,05 & 2,72 & 2,70 & 2,87 & 2,94 & 2,92 & 2,99 & 3,06 \\
\multicolumn{1}{c}{ > 25 tahun } & 3 & 3,58 & 2,61 & 2,71 & 3,05 & 2,81 & 2,94 & 3,05 & 3,38 \\
\hline
\end{tabular}


Training yang memadai yang telah diterima dari institusi (TR) dirasakan memuaskan hanya pada golongan masa kerja 2,5 s/d 5 tahun. Untuk semua golongan masa kerja menyatakan kurang memadai atas training yang diterima, dengan nilai kurang dari 3. Nilai terendah dinyatakan pada karyawan dengan golongan masa kerja 20,5 s/d 25 tahun dengan nilai 2,70.

Persepsi karyawan terhadap teknologi informasi yang dimiliki institusional untuk pekerjaannya (TI) dirasakan oleh karyawan telah memuaskan, terutama untuk golonagan masakerja 2,5 s/d 5 thn dengan nilai tertinggi 3,37 . Hanya golongan karyawan masa kerja 20,5 s/d 25 tahun yang merasa kurang puas atas teknologi informasi yang dimiliki institusional dengan nilai terendah 2,87.

Persepsi karyawan tentang lingkungan kerja yang disediakan institusi (WE) dinyatakan memuaskan hanya pada golongan masa kerja 2,5 s/d 5 tahun sedangkan golongan masa kerja lain mnyatakan kurang puas dengan memberikan nilai kurang dari 3. Nilai terendah untuk tingkat kepuasan lingkungan kerja diberikan pada karywan dengan golongan masa kerja 15,5 s/d 20 tahun dengan nilai 2,64.

Kepuasan karyawan terhdap aspek design pekerjaan (WD) dinyatkan puas, oleh karyawan dengan golongan masa kerja 2,5 s/d 5 tahun sedangkan golongan masa kerja lain mnyatakan kurang puas dengan memberikan nilai kurang dari 3. Nilai terendah untuk tingkat kepuasan karyawan terhadap aspek design pekerjaan dinyatakan oleh karyawan dengan golongan masa kerja 5,5 s/d 10 tahun dengan nilai 2,67.

Persepsi karyawan terhadap lingkungan kerja (CSC) dinyatakan memuaskan dengan niali lebih dari 3 oleh karyawan dengan golongan masa kerja 2,5 s/d 5 tahun, $15,5 \mathrm{~s} / \mathrm{d} 20$ tahun dan golongan masa kerja $>25,5$ tahun sedangkan golongan masa kerja lain menyatakan kurang puas dengan memberikan nilai kurang dari 3. Nilai terendah dinyatakan oleh karyawan golongan masa kerja 5,5 s/d 20 tahun dengan nilai 2,29.

Komitment karyawan terhadap organisasi (OC). Semua karyawan pada semua golongan masa kerja menyatakan merasa memiliki komitmen terhadap organisasi yang dinyatakan dengan nilai lebih dari 3. Nilai terendah atas komitment terhadap organisasi dinyatakan oleh karyawan dengan golongan masa kerja 15,5 s/d 20 tahun dengan nilai 2,98 .

\section{Pengaruh Langsung Prediktor Persepsi Layanan terhadap Iklim Layanan Pelanggan}

Hasil regresi variable Imbalan (RW), Suara Pekerja (EV), Teknologi dan Informasi (IT), Desain Kerja (WD), Lingkungan Kerja (WE) dan Pelatihan (TR) sebagai variable bebas terhadap Iklim Layanan Pelanggan (CSC) menunjukkan variable Suara Pekerja (EV), Teknologi dan Informasi (IT), Desain Kerja (WD), Lingkungan Kerja (WE), dan Pelatihan (TR) adalah signifikan pada $\mathrm{p} \leq$ 0,10 . Hal ini mengindikasikan variablevariabel tersebut secara parsial berpengaruh terhadap Iklim Layanan Pelanggan (CSC). Sedangkan variable Imbalan (RW) tidak signifikan.pada $\mathrm{p} \leq 0,10$, yang berarti variable imbalan (RW) tidak berpengaruh terhadap Iklim Layanan Pelanggan (CSC).

Dari hasil olah data juga diperoleh nilai $\mathrm{F}$ sebesar 31,171 dengan signifikansi dibawah $10 \%$, hal ini menunjukkan variable Imbalan (RW), Suara Pekerja (EV), Teknologi dan Informasi (IT), Desain Kerja (WD), Lingkungan Kerja (WE) dan Pelatihan (TR) secara simultan berpengaruh terhadap Iklim Layanan Pelanggan (CSC).

Dari model persamaan regresi didapatkan nilai $\mathrm{R}^{2}$ sebesar 0,803 yang berarti bahwa hanya sebesar $80,3 \%$ variable dependen Iklim Layanan Pelanggan dijelaskan oleh variable independennya, sedangkan sisanya sebesar $19,7 \%$ dijelaskan oleh variabel lain yang tidak masuk dalam model. 
Tabel 5: Hasil Regresi Prediktor Persepsi Layanan terhadap Iklim Layanan Pelanggan

\begin{tabular}{|l|l|l|c|c|c|}
\hline \multicolumn{1}{|c|}{ Variabel } & Koefisien & Nilai & $\begin{array}{c}\text { Simpangan } \\
\text { Standar }\end{array}$ & $\mathrm{T}$ & $\mathrm{P}$ \\
\hline Konstanta & $\beta_{0}$ & 3,994 & 2,323 & $-1,719$ & 0,092 \\
Imbalan (RW) & $\beta_{1}$ & 0,109 & 0,122 & 0,900 & 0,373 \\
Suara Pekerja (EV) & $\beta_{2}$ & 0,414 & 0,106 & 3,899 & 0,000 \\
Desain Kerja (WD) & $\beta_{3}$ & 0,243 & 0,113 & 2,155 & 0,036 \\
Lingk. Kerja (WE) & $\beta_{4}$ & 0,399 & 0,150 & 2,664 & 0,011 \\
Tek. \& Informasi (IT) & $\beta_{5}$ & 0,227 & 0,106 & 2,151 & 0,037 \\
Pelatihan (TR) & $\beta_{6}$ & 0,116 & 0,064 & $-1,822$ & 0,075 \\
\hline
\end{tabular}

$\mathrm{R}^{2}=0,803 \mathrm{~F}=31,171$ Signifikan $\mathrm{p} \leq 0,0001$

Durbin Watson test $=1,574$

Hasil-hasil ini memberi dukungan terhadap hipotesis 2,3,4,5 dan 6, sedangkan hipotesis 1 yang menguji pengaruh pemberian reward terhadap Iklim Layanan Pelanggan tidak terbukti secara signifikan. Hasil regresi selengkapnya terdapat pada tabel 5 di atas.

\section{Pengaruh Langsung Prediktor Persepsi Layanan terhadap Komitment Organisasional}

Hasil regresi variable Imbalan (RW), Suara Pekerja (EV), Teknologi dan Informasi (IT), Desain Kerja (WD), Lingkungan Kerja (WE) dan Pelatihan (TR) sebagai variable bebas terhadap Komitmen Organisasional (OC) menunjukkan variable Imbalan (RW), Suara Pekerja (EV), Lingkungan Kerja (WE) dan Pelatihan (TR) adalah signifikan pada $\mathrm{p} \leq 0,10$. Hal ini mengindikasikan variable-variabel tersebut secara parsial berpengaruh terhadap Komitmen Organisasional (OC). Sedangkan variable Teknologi dan Informasi (IT) dan Desain Kerja (WD) tidak signifikan.pada $\mathrm{p} \leq 0,10$, yang berarti variable-variabel tersebut tidak berpengaruh terhadap Komitmen Organisasional (OC).

Dari hasil olah data juga diperoleh nilai $F$ sebesar 9,674 dengan signifikansi dibawah $10 \%$, hal ini menunjukkan variable Imbalan (RW), Suara Pekerja (EV), Teknologi dan Informasi (IT), Desain Kerja (WD), Lingkungan Kerja (WE) dan Pelatihan (TR) secara simultan berpengaruh terhadap Komitmen Organisasional (OC).

Dari model persamaan regresi didapatkan nilai $\mathrm{R}^{2}$ sebesar 0,558 yang berarti bahwa hanya sebesar $55,80 \%$ variable dependen Komitmen Organisasional (OC) dijelaskan oleh variable independennya, sedangkan sisanya sebesar 44,20\% dijelaskan oleh variable lain yang tidak masuk dalam model.

Hasil-hasil ini menunjukkan adanya dukungan terhadap hipotesis 7, meskipun ada beberapa variabel bebas yang tidak mempengaruhi komitmen organisasi, seperti variabel teknologi informasi dan desain kerja. Hasil regresi selengkapnya terdapat pada tabel 6 . 
Tabel 6 : Hasil Regresi Prediktor Persepsi Layanan terhadap Komitment Organisasional

\begin{tabular}{|l|l|l|l|l|l|}
\hline \multicolumn{1}{|c|}{ Variabel } & Koefisien & Nilai & \multicolumn{1}{c|}{$\begin{array}{c}\text { Simpangan } \\
\text { Standar }\end{array}$} & $\mathrm{T}$ & $\mathrm{P}$ \\
\hline Konstanta & $\beta_{0}$ & 7,678 & 3,096 & 2,480 & 0,017 \\
Imbalan (RW) & $\beta_{1}$ & 0,369 & 0,162 & 2,277 & 0,027 \\
Suara Pekerja(EV) & $\beta_{2}$ & 0,730 & 0,142 & 5,152 & 0,000 \\
Desain Kerja (WD) & $\beta_{3}$ & 0,008 & 0,150 & $-0,053$ & 0,958 \\
Lingk. Kerja (WE) & $\beta_{4}$ & 0,455 & 0,200 & $-2,280$ & 0,027 \\
Tek. \& Informasi (IT) & $\beta_{5}$ & 0,028 & 0,141 & $-0,197$ & 0,845 \\
Pelatihan (TR) & $\beta_{6}$ & 0,200 & 0,085 & 2,345 & 0,075 \\
\hline
\end{tabular}

$\mathrm{R}^{2}=0,558 \quad \mathrm{~F}=9,674$ Signifikan $\mathrm{p} \leq 0,0001$

Durbin Watson test $=1,531$

Pengaruh Langsung Komitment Organisasional terhadap Iklim Layanan Pelanggan

Tabel 7: Hasil Regresi Komitment Organisasional terhadap Iklim Layanan Pelanggan

\begin{tabular}{|l|l|c|l|c|c|}
\hline \multicolumn{1}{|c|}{ Variabel } & Koefisien & Nilai & $\begin{array}{c}\text { Simpangan } \\
\text { Standar }\end{array}$ & $\mathrm{T}$ & $\mathrm{P}$ \\
\hline Konstanta & $\beta_{0}$ & 11,200 & 3,021 & 3,708 & 0,001 \\
Komitment Org.(OC) & $\beta_{1}$ & 0,479 & 0,142 & 3,372 & 0,001 \\
\hline
\end{tabular}

$\mathrm{R}^{2}=0,182 \mathrm{~F}=11,369$ Signifikan $\mathrm{p} \leq 0,001$

Durbin Watson test $=1,373$

Hasil regresi variabel Komitmen Organisasional sebagai variabel bebas terhadap variabel Iklim Layanan Pelanggan sebagai variabel terikat, menunjukkan $\beta_{1}$ bernilai positif dan signifikan pada $\mathrm{p} \leq 0,05$. Hal ini berarti bahwa Komitmen Organisasional (OC) terbukti berpengaruh terhadap Iklim Layanan Pelanggan (CSC).

Dari model persamaan regresi didapatkan nilai $R^{2}$ sebesar 0,182 yang berarti bahwa hanya sebesar 18,2\% variabel Iklim Layanan Pelanggan (CSC) dijelaskan oleh variabel independennya, sedangkan sisanya sebesar $81,80 \%$ dijelaskan oleh variabel lain yang tidak masuk dalam model. Hasil regresi selengkapnya terdapat pada tabel 7 .

\section{Pengaruh Tidak Langsung Prediktor Persepsi Layanan terhadap Iklim Layanan Pelanggan yang di Mediasi Komitmen Organisasional.}

Untuk mengukur mediasi, Baron dan Kenny (1986), menyatakan bahwa per- samaan regresi harus diperkirakan dengan langkah-langkah sebagai berikut: pertama, mediator diregresikan pada variabel independen, kedua variabel dependen diregresikan pada variabel independen dan ketiga, variabel dependen diregresikan secara simultan baik pada variabel independen maupun mediator. Mediasi terjadi ketika kondisi berikut bisa dipertahankan: variabel independen (RW, EV, IT, WD, WE, TR) harus terkait dengan mediator (OC) pada persamaan pertama, variabel independen (RW, EV, IT, WD, WE, TR) harus terkait dengan variabel dependen (CSC) pada persamaan kedua; mediator (OC) harus terkait dengan variabel dependen (CSC) pada persamaan ketiga. Pengaruh variabel independen pada variabel dependen (seperti ditunjukkan oleh bobot beta) harus lebih rendah pada persamaan ketiga dibandingkan dengan persamaan kedua.

Tabel 8 menunjukkan hasil analisis regresi termediasi yang melibatkan persepsi 
pekerja tentang iklim layanan pelanggan di dalam organisasi mereka. Untuk tahap 1, mediator (Komitmen Organisasional) diregresikan secara parsial pada masingmasing dari keenam variabel independen, yakni Imbalan (RW), Suara Pekerja (EV), Pelatihan (TR), Lingkungan Kerja (WE), Desain Kerja (WD) dan Informasi \& Teknologi (IT). Hasilnya menunjukkan variabel Imbalan (RW), Suara Pekerja (EV), Pelatihan (TR), Desain Kerja (WD) dan Lingkungan Kerja (WE) adalah variabel yang memenuhi persyaratan untuk dimediasi, karena memiliki tingkat signifikansi $10 \%$, sedangkan Informasi \& Teknologi (IT) tidak berpengaruh terhadap Komitmen Organisasional.

Tabel 8: Hasil Analisis Regresi Termediasi

\begin{tabular}{|c|c|c|c|}
\hline Variabel Independen & $\begin{array}{l}\text { Iklim Layanan } \\
\text { Pelanggan (CSC) }\end{array}$ & $\begin{array}{c}\text { Komitmen } \\
\text { Organisasional }\end{array}$ & $\begin{array}{c}\text { Tingkat } \\
\text { Signifikan }\end{array}$ \\
\hline \multicolumn{4}{|l|}{ Imbalan (RW) } \\
\hline Tahap 1 & & 0,537 & $0,006^{*}$ \\
\hline Tahap 2 & 0,122 & & 0,591 \\
\hline Tahap 3 & $-0,158$ & & 0,477 \\
\hline Tahap 3 (Mediator) & 0,521 & & $0,010^{*}$ \\
\hline \multicolumn{4}{|l|}{ Suara Karyawan (EV) } \\
\hline Tahap 1 & & 0,587 & $0,000^{*}$ \\
\hline Tahap 2 & 0,864 & & $0,000 *$ \\
\hline Tahap 3 & 0,875 & & $0,000 *$ \\
\hline Tahap 3 (Mediator) & $-0,018$ & & 0,886 \\
\hline \multicolumn{4}{|l|}{ Pelatihan (TR) } \\
\hline Tahap 1 & & 0,268 & $0,010^{*}$ \\
\hline Tahap 2 & 0,293 & & $0,010^{*}$ \\
\hline Tahap 3 & 0,206 & & $0,027 *$ \\
\hline Tahap 3 (Mediator) & 0,321 & & $0,041^{*}$ \\
\hline \multicolumn{4}{|l|}{ Teknologi\&Informasi (IT) } \\
\hline Tahap 1 & & 0,131 & 0,344 \\
\hline Tahap 2 & 0,711 & & $0,000 *$ \\
\hline Tahap & 30,660 & & $0,000 *$ \\
\hline Tahap 3 (Mediator) & 0,390 & & $0,001 *$ \\
\hline \multicolumn{4}{|l|}{ Lingkungan Kerja (WE) } \\
\hline Tahap 1 & & 0,227 & $0,107 *$ \\
\hline Tahap 2 & 0,914 & & $0,000 *$ \\
\hline Tahap 3 & 0,847 & & $0,000 *$ \\
\hline Tahap 3 (Mediator) & 0,293 & & $0,002 *$ \\
\hline \multicolumn{4}{|l|}{ Desain Kerja (WD) } \\
\hline Tahap 1 & 0,252 & & $0,044^{*}$ \\
\hline Tahap 2 & 0,798 & & $0,000 *$ \\
\hline Tahap 3 & 0,733 & & $0,000 *$ \\
\hline Tahap 3 (Mediator) & 0,255 & & $0,011^{*}$ \\
\hline
\end{tabular}

*) Signifikan $\mathrm{p} \leq 0,10$ 
Tahap dua, variabel dependen (persepsi tentang Iklim Layanan Pelanggan) diregresikan secara parsial terhadap keenam variabel independen. Hasilnya menunjukkan hanya variabel Imbalan yang tidak signifikan, sedangkan variabel lainnya memenuhi persyaratan kedua untuk mediasi.

Tahap ketiga, persepsi tentang iklim layanan pelanggan diregresikan secara simultan pada komitmen organisasional dan salah satu dari keenam variabel independen. Proses ini diulang sebanyak enam kali, sehingga pada tahap ini ada 6 persamaan yang diuji. Hasilnya menunjukkan tidak semua koefisien mediator signifikan mempengaruhi Iklim Layanan Pelanggan. Mediator signifikan mempengaruhi Iklim Layanan Pelanggan jika dipadukan dengan variabel independen Pelatihan (TR), Teknologi \&Informasi (IT), Lingkungan Kerja (WE), dan Desain Kerja (WD). Berdasarkan hasil uji tahap 1 sampai 3, maka hanya variabel Pelatihan (TR), Lingkungan Kerja (WE), dan Desain Kerja (WD) yang memenuhi persyaratan untuk mediasi, dimana besaran beta untuk variabel tersebut mengalami penurunan dari tahap sebelumnya dan tetap signifikan. Hal ini menunjukkan bahwa variabel Komitmen organisasional secara parsial menjadi mediasi yang menghubungkan variabel Pelatihan (TR), Lingkungan Kerja (WE), dan Desain Kerja (WD) dengan persepsi karyawan tentang Iklim Layanan Pelanggan (CSC).

Banyak penelitian layanan pelanggan yang memusatkan perhatian pada usaha untuk menunjukkan keeratan hubungan antara pekerja dengan persepsi pelanggan tentang layanan (Schneider, Parkington dan Buxton, 1980), tetapi banyak organisasi yang menggeser fokus mereka pada variabel-variabel yang mempengaruhi persepsi pekerja tentang layanan. Sebagai contoh, Kellley (1992) telah mendeskripsikan usaha untuk membangun sebuah iklim organisasional untuk layanan diantara pekerja dari sebuah organisasi, yang komponen-komponennya meliputi dukungan manajemen dan sumber daya yang memadai agar pekerja mampu melakukan pekerjaan mereka dengan baik. Penelitian lebih lanjut dilakukan oleh David J.Lux, Steve dan Curtis, (1996) yang menguji variabel komitmen organisasional sebagai variabel mediator yang menghubungkan dukungan organisasional dan imbalan dengan layanan pelanggan.

Hipotesis 1 sampai 6 menguji variabel-variabel yang secara intuitif jelas penting dalam mempengaruhi persepsi karyawan tentang iklim layanan pelanggan di dalam organisasi mereka. Memberi imbalan karyawan untuk keunggulan layanan mereka, mendengarkan suara karyawan dan menyediakan informasi dan teknologi yang diperlukan karyawan untuk melakukan pekerjaan mereka dengan baik, menyediakan pelatihan yang memadai dan menyediakan lingkungan kerja yang memadai akan mempengaruhi persepsi karyawan tentang iklim layanan pelanggan. Dalam penelitian ini ternyata variabel imbalan (RW) ditemukan tidak mempengaruhi persepsi karyawan tentang iklim layanan pelanggan, tetapi berpengaruh terhadap komitmen karyawan pada organisasi. Hasil ini berbeda dari penelitian sebelumnya yang dilakukan David J.Lux, Steve dan Curtis, (1996). Bisa jadi hasil ini bersifat kasuistis yang memang hanya terjadi pada institusi tertentu yang belum mendesain variabel reward untuk kepentingan layanan pelanggan.

Hasil penelitian ini lebih mempertegas pandangan bahwa jika karyawan merasa diterima dengan baik dan suara mereka didengar pihak manajemen, mereka akan memperlakukan pelanggan dengan cara yang sama (Schneider, 1973; Ulrich dkk, 1991). Dengan menyediakan lingkungan kerja yang lebih nyaman dan 
pelatihan yang memadai, juga merupakan cara-cara yang bisa digunakan oleh institusi untuk menunjukkan perhatian mereka terhadap kesejahteraan karyawan.

Temuan penting lainnya dalam penelitian ini adalah bahwa hubungan antara variabel Pelatihan (TR), Lingkungan Kerja (WE), dan Desain Kerja (WD) dengan Iklim layanan Pelanggan secara parsial termediasi oleh komitmen organisasional. Temuan ini menunjukkan bahwa adanya pelatihan dan desain kerja yang baik, serta lingkungan kerja yang memadai mempengaruhi peningkatan komitmen organisasional dan selanjutnya mempengaruhi persepsi mereka tentang iklim layanan pelanggan.

\section{PENUTUP}

Penelitian ini didesain untuk menguji pengaruh variabel-variabel organisasional tertentu dengan persepsi karyawan tentang iklim layanan pelanggan di institusi mereka. Persepsi karyawan tentang iklim layanan pelanggan tidak boleh diabaikan oleh top manajemen. Berdasarkan penelitianpenelitian sebelumnya persepsi ini telah terbukti terkait dengan persepsi pelanggan tentang layanan dan penilaian kepuasan pelanggan. Sebuah implikasi dari temuan ini adalah bahwa sebagai ganti pengukuran persepsi kepuasan pelanggan, kita bisa mengukur persepsi karyawan tentang iklim layanan pelanggan. Jika persepsi ini bisa dipengaruhi, karyawan bisa termotivasi untuk menyediakan layanan pelanggan yang lebih baik. Ini bisa menjadi sebuah cara yang lebih baik untuk mengembangkan kepuasan pelanggan dibanding hanya dengan melalui sarana tradisional.

Layanan pelanggan tentu telah menjadi sebuah topik yang menarik, karena satusatunya yang bisa digunakan oleh sebuah institusi untuk membedakan diri dari kompetitornya adalah dengan cara menyediakan kualitas layanan yang lebih baik. Menyediakan layanan yang berkualitas menjadi masalah sentral di banyak organisasi, namun demikian bagaimana cara menyediakan layanan tersebut belum didefinisikan dengan baik. Banyak organisasi menggunakan sebuah pendekatan pintas dengan memberlakukan layanan pelanggan yang bersandar pada pekerja yang "ramah". Perkembangan terakhir menunjukkan banyak organisasi tertarik pada penemuan variabel organisasional kunci yang bisa membantu mereka membangun sebuah kelompok kerja yang berorientasi pada pelanggan yang solid. Penelitian ini menyoroti beberapa variabel organisasional yang bisa membantu organisasi melakukan hal tersebut.

\section{DAFTAR PUSTAKA}

Amanda, Beatson. dkk. (2008). Service staff attitudes, Organisational Practices and Performance Drivers. Journal of Management \& Organization, vol 14, 168-179.

Angela, Martin. (2008). Service climate and employee weel being in higher education, Journal of Management \& Organization, vol 14,155-167.

Bennet, A. (1990). Many Consumers Expect Better Service and Say The Willing to Pay for It. Wall Street Journal, November, vol 12.

Bennet, R. (1992). Gaining a Competitive Advantage Through Customer Satifaction. Journal of Bank Marketing, 24 (12).

Brown, K.A. and T.R Mitchell. (1993). Organizational Obstacles: Links With Financial Performance, Customer Satisfaction and Job Satisfaction in a Service Environment. Journal of Human Relations, vol 46 (6).

De Vellis, R.F. (1992), Scale Development: Theory and Applications. $2^{\text {nd }}$ ed London: Sage Publications. 
David J.Lux, Steve and Curtis. (1996). Factors Influencing Employee Perceptions of Customer service Climate. Journal of Market Focused Manajement, I, 65-86

Kelley, S.W. (1992). Developing Customer Orientation Among Service Employees. Journal of Academy of Marketing Science. Vol 20 (1).

Schneider, B. (1973). The Perseptionof Organizational Climate: The Customer's View. Journal of Applied Paychology, vol 57 (3).

Schneider, B. (1980). The Service Organization: Climate Is Crucial. Organizational Dynamic's. 9 (2).

Schneider, B and D.E.Bown. (1985). Employee and Customer Perceptions of Service In Bank's: Replication an Extension. Journal of Applied Psychology, Vol 70 (3).
Schneider, B. B. Chung and K.P. Yusko. (1993). Service Climate for Service Quality. Current Direction in Psychological Acience. 2 (5).

Tornow, W. and J.W. Wiley. (1981). Service Quality and Management Parctices: A Look at Employee Atitude's, Customer Satisfaction and BottonLine Consequences. Journal of Human Resource Planning, 14 (2).

Voon, dkk. 2009). Linking Service Climate to Organizational Performance: Evidence from Sarawak. Journal of Business and Society, vol 10,120135.

Wiley J.W. (1991). Customer Satisfaction: A Supportive Work Environment and Its Financial Cost. Journal of Human Resource Planning, Vol 14 (2). 